\title{
Perceptions of Library Use by Faculty and Students: A Comparison
}

\author{
Mary K. Sellen and Jan Jirouch
}

\begin{abstract}
Two equivalent questionnaires were distributed to faculty and students to determine (1) if faculty expectations of student library use differed from the students' perceptions of their actual use; and (2) if expectations and use were affected by college division, student class level, or class level taught. The results indicated that differences existed but that these differences were not affected by college division, class level taught, or student class level. Implications were that students will continue to utilize elementary library research skills and access secondary sources until faculty expectations are communicated directly to the students and are translated into organized library instruction.
\end{abstract}

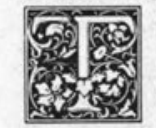

he methods of examining use of library materials have been diverse. With economic pressures being applied to acquisitions' budgets, attempts to determine and measure what has been used in the library have assumed singular importance. To date, use studies have become common practice in assessing the type of library materials used by various clientele. Most of these studies have been based on measures of circulation and/or surveys of individual use. $^{1}$

In a college library, the use of library materials has not been determined solely by individual interest and need. Faculty expectations for student use have been a compounding factor in the use process. ${ }^{2}$ For the most part, faculty have come from research backgrounds and have expected students to use various library resources regardless of the class taught. There also have been indications that the use and type of use of library materials have been influenced by the academic discipline to which the faculty member or student belongs and by the class level taught, or in the case of the student, the class status.
This study was designed to expand upon the use study and to determine, by means of a survey, the relationship between the respondent's academic status and her or his perceptions of expectations and actual use of library materials.

The following research questions were addressed in this study:

1. Did faculty expectations of student library use differ from the students' perceptions of their actual library use?

2. Did faculty from the different college divisions have varying expectations of student library use and did the class levels taught affect these expectations?

3 . Did students from the different college divisions have varying perceptions of their library use and did class level affect these perceptions?

4. Did subjects within division and within class level, or class level taught, respond equally across response choices to the various questions concerning use of library materials?

\section{METHODOLOGY}

This study was conducted at Pennsylvania State University-Behrend College, an

Mary K. Sellen is head librarian, Pennsylvania State University-Behrend College, Erie, Pennsylvania 16563. Jan Jirouch is professor of psychology, Northern State College, Aberdeen, South Dakota 57401. 
independent four-year college in the PSU system enrolling two thousand students. The three college divisions, namely Arts and Humanities, Social and Behavioral Sciences, and Natural Science and Engineering, were the academic disciplines identified for purposes of this study.

Two equivalent questionnaires were developed for faculty and students for the purpose of eliciting (1) the use of or exposure to library instruction and (2) expectations of use or use of library materials. The subjects were requested to respond to the questions by selecting an appropriate individual response from a series of preselected choices. The choices were determined on the basis of librarian observations and expectation of library utilization by faculty and students.

The student questionnaires were given over a two-week period in the winter term of 1982 . Every student using the Behrend College Library during that time was asked to complete the survey. One hundred and forty-nine students were contacted. Of this sample, 129 questionnaires were completed. This group comprised 6 percent of the student body. The three college divisions were represented in the sample in the following manner: 17 percent from Arts and Humanities, 45 percent from Social and Behavioral Sciences, and 38 percent from Natural Science and Engineering. Sixty-seven percent of these students were freshmen or sophomores and 38 percent were juniors or seniors.

During the same time period the entire faculty received the questionnaire. Thirtyseven percent of the faculty completed and returned the survey. Of this number, 31 percent were from the division of Arts and Humanities, 41 percent were from the division of Social and Behavioral Sciences, and 28 percent were from the division of Natural Science and Engineering. Further classification revealed that 54 percent of the faculty taught freshman-sophomore classes only and 46 percent taught across all class levels.

The results of the survey were presented in frequencies and were analyzed by the chi-square statistic. This procedure was utilized because of the nominal nature of the data. Frequencies were tabu- lated and the chi-square analysis was computed using the subprogram crosstabs in SPSS.

\section{RESULTS}

The research questions were addressed in several research hypotheses. The main research hypothesis tested the condition of no difference between faculty expectations of student use of library materials and students' actual use of these materials. The results shown in table 1 indicated that faculty and students differed significantly $(p<.05)$ on four of the seven questions pertaining to library orientation and use of library materials.

Although the majority of faculty and students responded positively to general required use of the library materials, a sufficient number of students indicated a lack of required use to create a significant difference between faculty expectation of and students' perceptions of required library use. Faculty and students also differed significantly in their preference of source materials. Students tended more toward the use of books, whereas faculty expected students to use periodicals. The preferred publication dates of periodicals was another area of difference between the two groups. Faculty responded across dates, whereas students strongly preferred recently published periodicals. The fourth area of difference between faculty and students was in the type of material to be used or used in research and class preparation. Faculty completely disregarded the use of encyclopedias and dictionaries. Twenty-six percent of the students reported these materials as viable sources of information. Faculty also expected indexes, abstracts, and other materials to be used more in research and class preparation. Students indicated less use of these materials. The remaining three items showed similar responses for both faculty and students. Both groups were evenly divided on library orientation as part of class instruction, both indicated similar assignments of materials, and both preferred books with current publication dates.

Two hypotheses dealt with the second research question of the study. The first of these hypotheses stated that no differ- 
TABLE 1

FACULTY/STUDENT PERCEPTIONS OF LIBRARY USE

\begin{tabular}{|c|c|c|c|c|c|}
\hline Library Use & \multicolumn{2}{|c|}{ Faculty } & \multicolumn{2}{|c|}{ Students } & $x^{2}$ \\
\hline Library orientation as part of class instruction: & & & & & .03 \\
\hline Yes & 20 & 52 & 66 & 51 & \\
\hline 1 & 19 & 48 & 63 & 49 & \\
\hline $\begin{array}{l}\text { Required use of library material: } \\
\text { Yes }\end{array}$ & & & & & $9.00^{*}$ \\
\hline e & $\begin{array}{r}39 \\
0\end{array}$ & $\begin{array}{r}100 \\
0\end{array}$ & $\begin{array}{r}105 \\
24\end{array}$ & $\begin{array}{l}81 \\
19\end{array}$ & \\
\hline Type of material assigned for use: & & & & & 3.91 \\
\hline Reserve materials & 3 & 8 & 21 & 20 & \\
\hline Materials for research & 11 & 28 & 33 & 31 & \\
\hline Combined use of reserve and research material & 19 & 49 & 38 & 36 & \\
\hline Combined use of reserve, research, and other material & 6 & 15 & 14 & 13 & \\
\hline $\begin{array}{l}\text { Preferred sources for use: } \\
\text { Books }\end{array}$ & & & & & $13.25^{*}$ \\
\hline $\begin{array}{l}\text { Books } \\
\text { Periodicals }\end{array}$ & 23 & $\begin{array}{l}28 \\
59\end{array}$ & $\begin{array}{l}65 \\
60\end{array}$ & $\begin{array}{l}51 \\
41\end{array}$ & \\
\hline Both & 5 & 13 & 2 & 2 & \\
\hline Perceived periodical relevance by years: & & & & & $8.30^{\star}$ \\
\hline 1980 -present & 18 & 46 & 77 & 62 & \\
\hline $1975-79$ & 3 & 8 & 17 & 14 & \\
\hline $1970-74$ & 0 & 0 & 1 & 1 & \\
\hline $\begin{array}{l}\text { All } \\
\text { Perceived book relevance by years: }\end{array}$ & 18 & 46 & 28 & 23 & \\
\hline $\begin{array}{l}\text { Perceived book relevance by years: } \\
1980 \text {-present }\end{array}$ & 18 & 46 & 49 & 39 & 0.41 \\
\hline $1975-79$ & 4 & 10 & 24 & 19 & \\
\hline 1970-74 & 1 & 3 & 10 & 8 & \\
\hline All & 16 & 41 & 43 & 34 & \\
\hline $\begin{array}{l}\text { Material used or to be used (by students) in research and class prepa- } \\
\text { ration: }\end{array}$ & & & & & $12.71^{*}$ \\
\hline Indexes and abstracts & 13 & 36 & 31 & 24 & \\
\hline Encyclopedias and dictionaries & 0 & 0 & 33 & 26 & \\
\hline Books in general collection & 15 & 42 & 49 & 38 & \\
\hline Other (govt. documents, bibliographies, etc.) & 8 & 22 & 16 & 12 & \\
\hline
\end{tabular}

${ }^{*} P<.05$

ences were expected between faculty members in the three college divisions in their responses to library orientation and expected student use of library materials; the second hypothesis was that no differences were expected between the faculty teaching lower-level undergraduate classes and the faculty teaching across all class levels in their responses to library orientation and library materials to be used by students. The data presented in table 2 and table 3 clearly indicated that faculty members were similar in their responses across divisions and across class levels. Only one significant chi-square value appeared between the divisions. This difference was due to a definitive preference for indexes and abstracts on the part of the faculty in Natural Science and Engineering.

An analysis of response choices for faculty within the specific college divisions, when classified by class level taught, revealed significant preferences for library materials to be used by students. It should be noted that although there were significant differences within groups in many cases, these differences were either similar across all groups or they were not of sufficient magnitude to create a significant difference between divisions or between class-level groupings.

According to the data in table 2 and table 3 , a significant number of faculty in the division of Arts and Humanities and the division of Social and Behavioral Sciences, as well as the faculty teaching only freshman and sophomore courses, believe library orientation could be compatible with their discipline. Furthermore, all faculty required their students to use the library, but they were divided on their inclusion of library orientation in class instruction. 
TABLE 2

DIVISION FACULTY PERCEPTIONS OF LIBRARY USE FOR STUDENTS

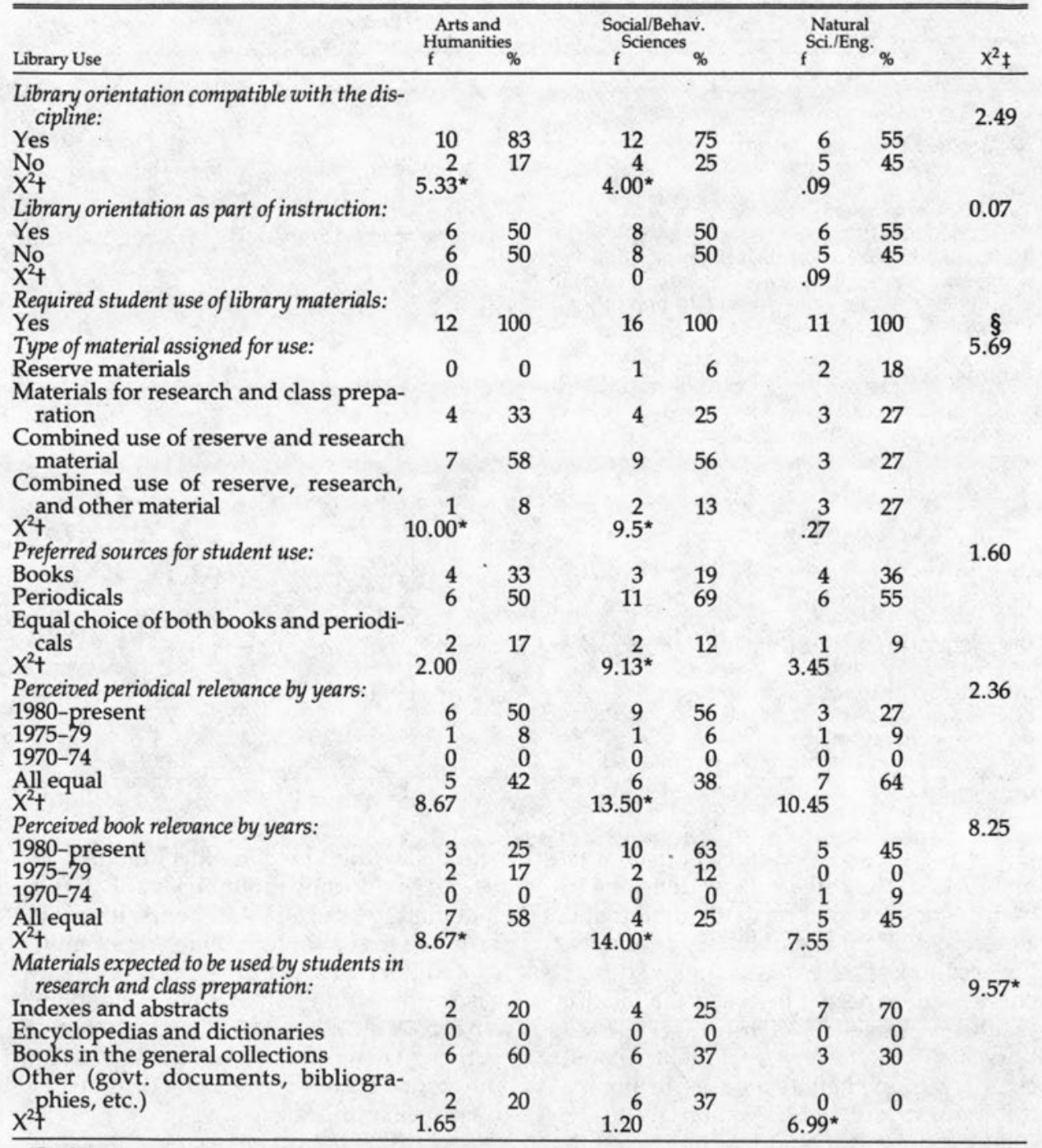

$* P<.05$

tWithin division $\mathrm{X}^{2}$.

$\ddagger$ Between division $X^{2}$.

$\S$ Not applicable due to 100 percent yes response.

As indicated by the responses to the type of material assigned for library use, faculty teaching across all class levels and faculty in the division of Social and Behavioral Sciences showed significant preference for a combined use of reserve and research material for student use. The significant chi-square value that appeared for those faculty members in Arts and Humanities was due more to an empty cell phenomena than to any real differences in response choices.

Faculty in Social and Behavioral Sciences and those faculty teaching 
TABLE 3

FACULTY PERCEPTIONS OF LIBRARY USE FOR STUDENTS ACCORDING TO CLASS LEVEL TAUGHT

\begin{tabular}{|c|c|c|c|c|c|}
\hline Library Use & \multicolumn{2}{|c|}{$\underset{f}{\text { Fr.-Soph. Only }} \%$} & \multicolumn{2}{|c|}{ 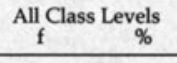 } & $x^{2} t$ \\
\hline Library orientation compatible with the discipline: & & & & & 0.13 \\
\hline Yes & 15 & 71 & 13 & 72 & \\
\hline 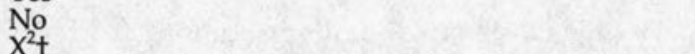 & $3.86^{*}$ & 29 & $\begin{array}{r}5 \\
356\end{array}$ & 28 & \\
\hline Library orientation as part of instruction: & & & & & 0.72 \\
\hline Yes & 12 & 57 & 8 & 44 & \\
\hline No & 9 & 43 & 10 & 56 & \\
\hline 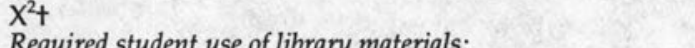 & 0.43 & & 0.22 & & \\
\hline $\begin{array}{l}\text { Required student use of library materials: } \\
\text { Yes }\end{array}$ & 21 & 100 & 18 & 100 & $\S$ \\
\hline Type of material assigned for use: & & & & & 2.07 \\
\hline Reserve materials & 2 & 10 & 1 & 6 & \\
\hline Materials for research and class preparation & 7 & 33 & 4 & 22 & \\
\hline Combined use of reserve and research material & 8 & 38 & 11 & 61 & \\
\hline $\begin{array}{l}\text { Combined use of reserve, research, and other material } \\
X^{2}+\end{array}$ & 4.33 & 19 & $13.56^{*}$ & 11 & \\
\hline $\begin{array}{l}\text { Preferred sources for student use: } \\
\text { Books }\end{array}$ & 5 & & 6 & & 1.06 \\
\hline Periodicals & 14 & 66 & 9 & 50 & \\
\hline $\begin{array}{l}\text { Equal choice of both } \\
X^{2}+\end{array}$ & $\stackrel{2}{2}$ & 10 & 3 & 17 & \\
\hline Perceived periodical relevance by years: & $11.14^{*}$ & & & & 1.02 \\
\hline 1980 -present & 11 & 52 & 7 & 39 & \\
\hline $1975-79$ & 1 & 5 & 2 & 11 & \\
\hline $1970-74$ & 0 & 0 & 0 & 0 & \\
\hline All & 9 & 43 & & 50 & \\
\hline $\begin{array}{l}\mathrm{X}^{2} \mathrm{t} \\
\text { Perceived book relevance by years: }\end{array}$ & 17.67 & & $11.78^{\star}$ & & 3.01 \\
\hline $\begin{array}{l}\text { Perceived book relevance by years: } \\
1980 \text {-present }\end{array}$ & 8 & 38 & 10 & 56 & \\
\hline $1975-79$ & 3 & 14 & 1 & 6 & \\
\hline $1970-74$ & 0 & 0 & 1 & 6 & \\
\hline All & 10 & 48 & & 33 & \\
\hline $\begin{array}{l}\mathrm{X}^{2}+ \\
\text { Materials expected to be used by students in resea }\end{array}$ & $11.95^{\star}$ & & $12.21^{*}$ & & \\
\hline $\begin{array}{l}\text { Materials expected to be used by students in research and cla } \\
\text { preparation: }\end{array}$ & & & & & 1.36 \\
\hline Indexes and abstracts & 8 & 40 & 5 & 28 & \\
\hline Encyclopedias and dictionaries & 0 & 0 & 0 & 0 & \\
\hline Books in the general collections & 9 & 45 & 6 & 33 & \\
\hline Other (govt. documents, bibliographies, etc.) & 3 & 15 & 5 & 28 & \\
\hline$x^{2} t$ & $10.80^{\star}$ & & 4.67 & & \\
\hline
\end{tabular}

$* \mathrm{P}<.05$

tWithin class $\mathrm{X}^{2}$

$\ddagger$ Between class level taught $X^{2}$.

$\S \mathrm{X}^{2}$ not applicable due to 100 percent yes response.

freshman-sophomore courses indicated a significant preference for student use of periodicals. When periodicals were assigned, all groups selected both current publication dates and all publication dates as relevant sources of information. Current publication dates for books were a significant response choice for the faculty teaching across all class levels and for the faculty in Social and Behavioral Sciences. Again, care must be taken in the accep- tance of the significant chi-square value for periodical relevance for faculty teaching freshmen and sophomores. These values were contributed to by the empty cell and not to real differences between response choices.

For materials expected to be used by students in research and class preparation, the only viable significant response choice appeared for faculty in the division of Natural Science and Engineering. These indi- 
viduals expected students to primarily use indexes and abstracts in their research and class preparation. The significant $c_{\text {...i- }}$ square value that appeared for faculty teaching freshmen and sophomores was again the result of the empty cell.

A similar set of hypotheses dealt with the third research question; namely that (1) no differences were expected between students in the three college divisions in their exposure to and use of library materials, and that (2) no differences were expected between lower-level undergraduates and upper-level undergraduates in their exposure to and use of library materials. Results presented in table 4 and table 5 confirmed these two hypotheses.

In order to address the fourth research question, the results were analyzed for within-division and within-class response choice differentiation. It was found that although a significant number of students indicated they were required by instructors to use the library, there was not a significant number reporting exposure to a library tour or library orientation as a part of class instruction. Also, the students were similar across divisions in not identifying specific types of assigned library material. Only the lower-level undergraduate students perceived particular types of material as being assigned by their instructors for class use.

The students in all classification groups chose either books or periodicals as preferred sources of information. They did not indicate a use of a combination of the two sources. The lack of response to this option contributed to the significant chisquare value for all groups; however, when the low cell was removed, neither books nor periodicals emerged as a significant choice.

There was a significant preference across groups for current periodical publication dates. The one exception was the division of Arts and Humanities. These students selected either current or all dates as their most relevant sources.

Similar responses appeared for book relevance within the various groupings. However, the significance was not due to a singular preference for current book dates but rather was due to a very equal distribution of responses to both current dates and dates spanning all years.

For materials used in research and class preparation, students, regardless of classification, indicated a preference for books. For those students in Natural Science and Engineering and for those classified as freshman-sophomore students, this preference contributed to the significant chi-square value. Student choices in the other groupings were more evenly distributed across all choice options.

\section{DISCUSSION}

The results of this study showed that differences existed between faculty expectations of students' library use and the students' perceptions of library use to supplement in-class materials. The differences indicated that students were either not perceiving and/or acting upon faculty expectations or that faculty were not communicating their expectations for library use to the students. This assumption was substantiated by the fact that 45 percent of the responding faculty in the division of Natural Science and Engineering did not indicate orientation as compatible with their instruction, nor did they indicate use of orientation; and in both the division of Arts and Humanities and the division of Social and Behavioral Sciences the faculty were equally divided when indicating use of orientation as part of instruction. It could, therefore, be concluded that many times faculty were not making introductory library orientation available to students in the course of instruction, even though all faculty considered library usage as a required activity.

Student responses corroborated this assumption. Responses showed that half of the students in this sample were not receiving even a basic orientation tour, much less library instruction. Also, students did not perceive required library use as strongly as faculty. In conjunction with this it was interesting to note that only 6 percent of the student population used the library over a two-week period. These facts supported the contention that students, when left on their own to use the library for academic purposes, did not make even minimum use of this resource 
TABLE 4

DIVISION STUDENT PERCEPTIONS OF LIBRARY USE

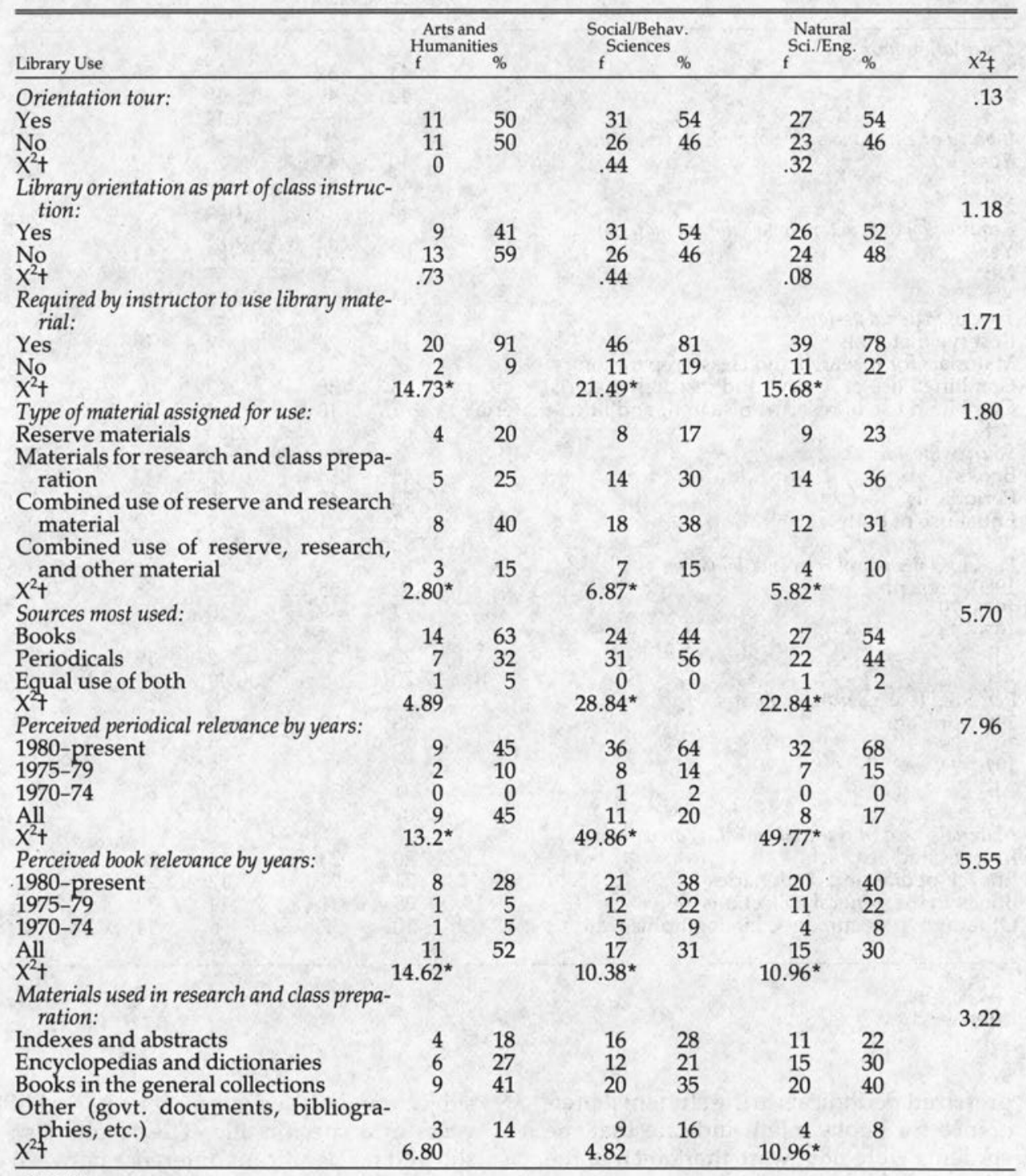

${ }^{*} P<.05$

+Within division $\mathrm{X}^{2}$

$\ddagger$ Between division $X^{2}$.

even though faculty very strongly expected such usage. These conditions could account also for the lack of differences between divisions and class level taught or class status, since no definitive expectations or orientation were being implemented.

Another significant difference between faculty and students occurred in the preferred sources for use. The fact that faculty 
TABLE 5

STUDENT PERCEPTIONS OF LIBRARY USE BY CLASS LEVEL

\begin{tabular}{|c|c|c|c|c|c|}
\hline Library Use & Fr.-Soph & & ${ }_{f}^{\mathrm{Jr}-\mathrm{Sr} \text {. }}$ & $\%$ & $x^{2} t$ \\
\hline \multicolumn{5}{|l|}{ Orientation tour: } & \multirow{3}{*}{0.32} \\
\hline Yes & 44 & 51 & 25 & 58 & \\
\hline No & 42 & 49 & 18 & 42 & \\
\hline $\begin{array}{l}\mathrm{X}^{2}+ \\
\text { Library orientation as part of class instruction: }\end{array}$ & .05 & & 1.14 & & \multirow{3}{*}{1.71} \\
\hline Yes & 40 & 47 & 26 & 61 & \\
\hline No & 46 & 53 & 17 & 39 & \\
\hline $\begin{array}{l}\mathrm{X}^{2}+ \\
\text { Required by instructors to use library material: }\end{array}$ & .42 & & 1.88 & & \multirow{3}{*}{0.06} \\
\hline Yes & 69 & 80 & 36 & 84 & \\
\hline $\begin{array}{l}\text { No } \\
X^{2}+\end{array}$ & $\begin{array}{r}17 \\
31.44^{*}\end{array}$ & 20 & $\stackrel{7}{7}$ & 16 & \\
\hline Type of material assigned for use: & & & & & \multirow[t]{5}{*}{2.33} \\
\hline Reserve materials & 14 & 20 & 7 & 19 & \\
\hline Materials for research and class preparation & 24 & 34 & 9 & 25 & \\
\hline Combined use of reserve and research material & 25 & 36 & 13 & 36 & \\
\hline $\begin{array}{l}\text { Combined use of reserve, research, and other material } \\
X^{2} t\end{array}$ & $12.62^{*}$ & 10 & $\begin{array}{r}7 \\
2.66\end{array}$ & 19 & \\
\hline $\begin{array}{l}\text { Sources most used: } \\
\text { Books }\end{array}$ & & 54 & & & \multirow[t]{3}{*}{0.72} \\
\hline $\begin{array}{l}\text { Books } \\
\text { Periodicals }\end{array}$ & $\begin{array}{l}45 \\
38\end{array}$ & $\begin{array}{l}54 \\
45\end{array}$ & 20 & $\begin{array}{l}47 \\
51\end{array}$ & \\
\hline $\begin{array}{l}\text { Equal use of both } \\
x^{2}+\end{array}$ & $\stackrel{1}{1}$ & 1 & 18 & 2 & \\
\hline Perceived periodical relevance by years: & & & & & \multirow[t]{10}{*}{5.51} \\
\hline $\begin{array}{l}1980 \text {-present } \\
1975-79\end{array}$ & $\begin{array}{r}52 \\
7\end{array}$ & $\begin{array}{r}65 \\
9\end{array}$ & 25 & $\begin{array}{l}58 \\
23\end{array}$ & \\
\hline $1970-74$ & 1 & $\begin{array}{l}9 \\
1\end{array}$ & $\begin{array}{r}10 \\
0\end{array}$ & $\begin{array}{r}23 \\
0\end{array}$ & \\
\hline All & 20 & 25 & 8 & 19 & \\
\hline $\begin{array}{l}\mathrm{X}^{2} \mathrm{t} \\
\text { Perceived book relevance by years: }\end{array}$ & $77.70^{*}$ & & $30.40^{*}$ & & \\
\hline 1980 -present & 33 & 38 & 16 & & \\
\hline $1975-79$ & 15 & 18 & 9 & 22 & \\
\hline $1970-74$ & 7 & 8 & 3 & 8 & \\
\hline All & 31 & 36 & 12 & 30 & \\
\hline$x^{2}+$ & $22.09^{\star}$ & & $9.00^{*}$ & & \\
\hline Materials used in research and class preparation: & & & & & \multirow[t]{6}{*}{0.82} \\
\hline Indexes and abstracts & 20 & 23 & 11 & 26 & \\
\hline Encyclopedias and dictionaries & 21 & 24 & 12 & 28 & \\
\hline Books in the general collections & 35 & 41 & 14 & 32 & \\
\hline Other (govt. documents, bibliographies, etc.) & 10 & 12 & 6 & 14 & \\
\hline $\bar{x}^{2} t$ & $14.74^{\star}$ & & 3.24 & & \\
\hline
\end{tabular}

${ }^{*} \mathrm{P}<.05$

tWithin class.

$\ddagger$ Æetween class.

preferred periodicals to the students' preference for books might indicate that the students were not aware that much of the relevant information for today's research across all disciplines was being generated from periodical sources and that many times this information did not make it into book form. Furthermore, when students did use periodicals, they tended to use only the most current issues, thereby possibly overlooking the fact that a particular subject might be covered over a period of years in a specific title. The results also showed no significant difference between class levels; thus it could be assumed that junior and senior students were continuing to perform much like freshmen and sophomores in their use of general library sources. Since upperclassmen could reasonably be expected to be similar to the faculty in their preference for periodicals, this difference could be attributed to a lack 
of library instruction on all class levels.

In addition to the different preferences in general sources, the types of specific library materials used by students were quite different from the materials that the faculty expected to be used, especially in the use of dictionaries and encyclopedias. One reason for this difference could be the fact that when students studied a particular subject for the first time, resources such as dictionaries and encyclopedias may be needed for basic definitions. However, since the trend to use books, dictionaries, and encyclopedias continued throughout the junior and senior years, a more plausible explanation might be that students were relying on their high school library research skills and emphasizing secondary sources but lacked both the knowledge of and the skills to access and use primary sources.

It appeared from the results of this study that if students were to be expected to successfully use sophisticated library resources for the enhancement of course material and for specific research endeavors, they needed to have knowledge of and the appropriate skills to use these resources. It was just as apparent that students neither acquired such knowledge or skill on their own nor did they seem to be inclined to utilize library resources without some external direction and motivation. Thus expectations for adequate and successful use of library materials must be translated into a combination of overt faculty direction and some type of organized graduated library instruction.

\section{REFERENCES}

1. There are many studies in print. Among those consulted for this study are the following: L. Hardesty, "Use of Library Materials at a Small Liberal Arts College," Library Research 3:261-82 (Fall 1981); R. M. Hayes, "The Distribution of Use of Library Materials: Analyses of Data from the University of Pittsburgh," Library Research 3:215-60 (Fall 1981); J. B. Whitlatch, "Library Use Patterns Among Full and Part-time Faculty and Students," College and Research Libraries 44:141-52 (Mar. 1983).

2. A. P. Naylor, Survey of Faculty Expectations: Student Homework, ED 188704 (Toledo, Ohio: Univ. of Toledo, 1974), p.2. 